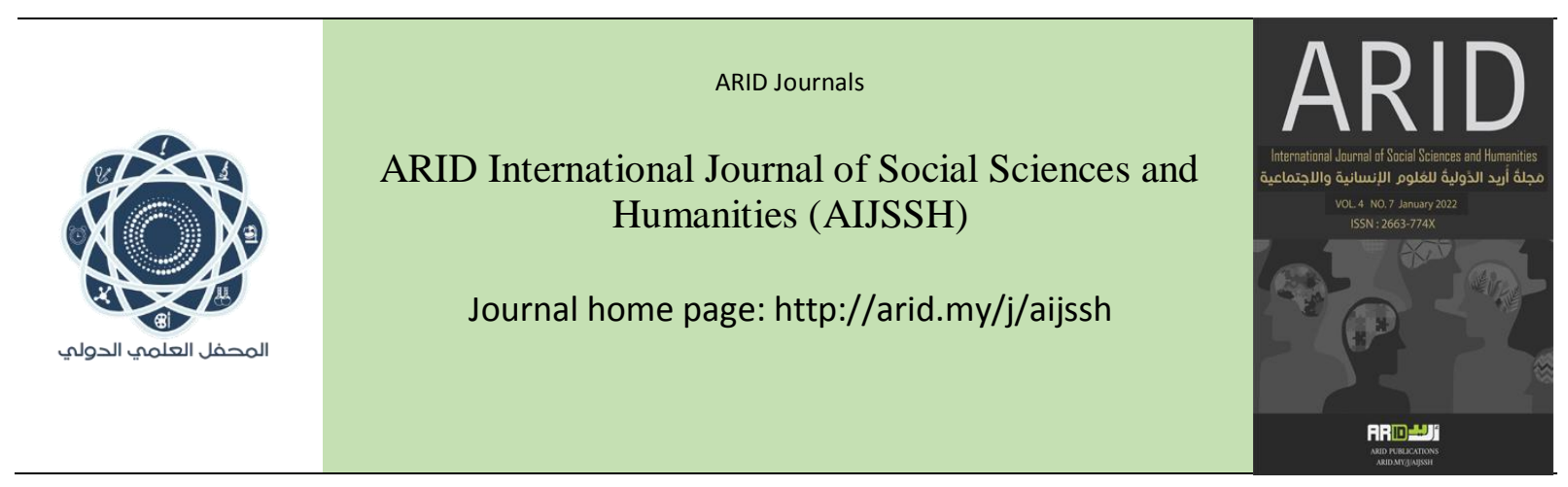

$$
\begin{aligned}
& \text { مَجلةُ أُريد الدَّوليةُ للعُلومِ الإنسانية والإجتماعية } \\
& \text { العدد السابع، البحلد الرابع، كانون الثاني } 2022 \text { م }
\end{aligned}
$$

\title{
"Teaching Strategies and Techniques to Motivate Students Learning English in the Preparatory Schools - Qatar", an Action Study
}

\author{
Muna A. Al-Shawi
}

Ministry of Education and Higher Education -State of Qatar

استراتيجيات التدريس / التعلم والتقنيات اللازمة لدفع الطلبة لتعلم اللغة الإنجليزية في المدارس الإعدادية في دولة قطر، دراسة إجرائية

\author{
منى الثاوي \\ وزارة التعليم والتعليم العالي - قطر
}




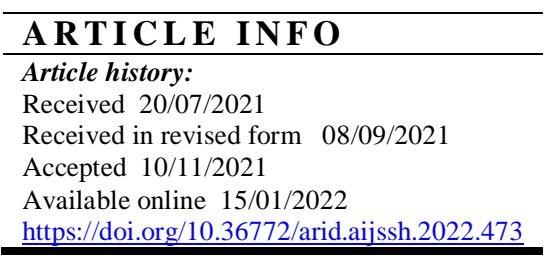

\begin{abstract}
Educational process has a great impact on the motivation of the learners, and these incentives (motives) are under the control of the teacher who directs the educational process. Accordingly, this action research is carried out to examine the effectiveness of certain teaching/ learning strategies and techniques applied for grade nine students chosen from Fatima Al-Zahra Preparatory School- Qatar to raise their motivation for learning English language. The findings show that external motivations (extrinsic) are among the most important factors in the success of learning English language, which are compensatory factors in the absence of the spontaneous desire to learn that language. The selected students have undergone varieties of active learning strategies, resources and tensive use of modern technology. The methods that are implemented in this study, include the designed questionnaire and the official exams sheets conducted on the targeted students. However, both qualitative and quantitative approaches are used to analyze the data.

The present study shows that the students are academically weak in English language, not well motivated to learn English, the learning strategies, resources, and techniques utilized in the classroom proved to be effective to motivate the students and are reflected on the academic performance of the students.
\end{abstract}

Therefore, the data analysis of the success ratio among the targeted students has shown an increase from $41.5 \%$ to $91.5 \%$ after the application of new strategies and techniques.

\title{
Key words: Motivation, Intrinsic, Extrinsic, learners
}




\section{الملخص}

تؤثر العملية التعليمية بشكل كبير على دافعية الطلبة للتعلم، و هذه الدو افع تخضع لسيطرة المعلم الذي يوجه العملية التعليمية داخل الصف.

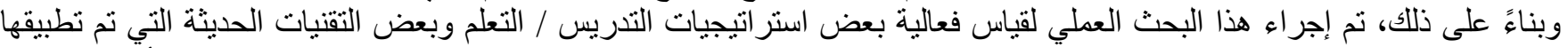

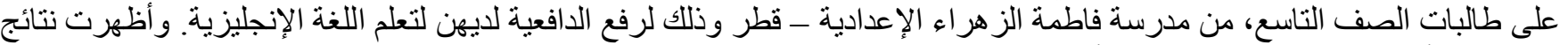

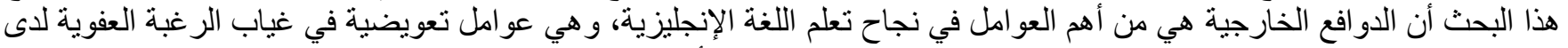

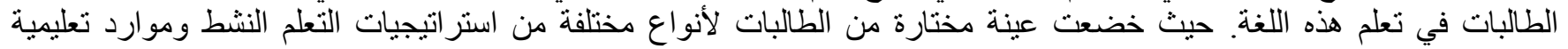

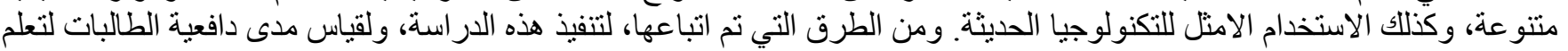

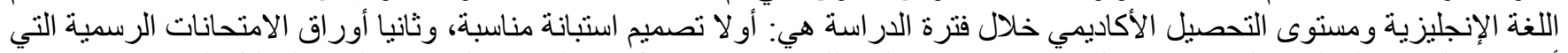
أجريت على فئة الطالبات المستهدفات بالدر اسة. بالإضافة إلى ذللك، تم استخدام كل من النهجين النوعي والكئ الكمي لتحليل البيانات.

أظهرت هذه الدر اسة أن غالبية الطالبات ضعيفات في اكتساب مهار ات اللغة الإنجليزية، وليس لديهن دافعية جيدة لتعلم هذه اللغةة، وقد

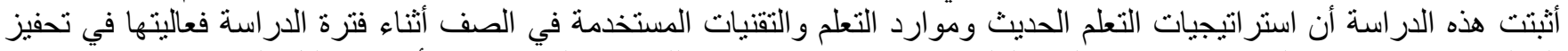

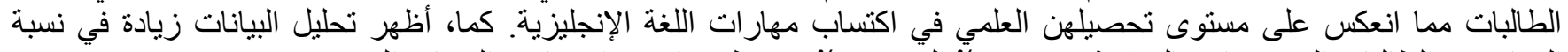
النجاح بين الطالبات المستهدفات بالدر اسة من 41.5\% إلى في 91.5\% بعد تطبيق الاستر اتيجيات والتقنيات الجديدة. 


\section{Introduction}

The educational-learning process is exposed to many problems and some of these problems are due to the lack or decrease of motivation for learning. However, learners justify their failure by saying that the teacher did not urge them to learn where are teachers blame the learners for being lazy and inactive. In this respect, Al-Sibaae (2001) [1] states that "Most of the students are indifferent to learn English. They do not focus on explaining of their teachers, and they spend most of the school's day between sleeping and playing". He adds that this is due to many reasons among them, the students' boredom from the teaching methods, the too many examinations, as well as the availability of other methods of learning outside the school such as the private lessons, which keep them away from attending their schools or involving in the lesson's stages. Hence, this topic needs more investigation about all sides of the educational process: administration, teachers, curriculum and parents due to the drop of the academic level of the students. The problem of low motivation has recently become a turn and a phenomenon that needs a stand still on its reasons and then to reach appropriate solutions in order to improve the level of students' language learning process.

Nowadays, demotivation is receiving great attention from the Ministry of Education and Higher Education in Qatar, School administrations and English teachers but this problem still exists, especially in the independent schools. This issue has led to low level of achievement in different subjects such as the Arabic, the English languages and mathematics [2]. As a result, this issue has become so important that one cannot turn a blind eye or overlook it, due to different reasons related to the student himself, the teacher, the surrounding environment, the curriculum, educational means and others. However, the biggest role depends on the teachers in finding appropriate ways and techniques for stimulating, enhancing and encouraging students to study and participate actively in the class.

This work identifies this problem, describes its manifestations, and mention the reasons and propose the applicable solutions to it. 


\section{The Problem}

Although some students seem naturally enthusiastic about learning English language, but a high ratio in the class needs/ expects other considerations to inspire, challenge and stimulate. Consequently, low motivation is considered one of the major problems that encounter teachers while teaching students in the preparatory schools in Qatar. It is therefore the teachers' concern to find ways and techniques to reach the students' motivation to the highest level of language as well as raising the academic level in schools for better standards. Therefore, the aim of the present study is to investigate the problem of low-motivation of the students to acquire English as a second language in the preparatory schools in Qatar putting special focus on the reasons and the efficient factors that motivate student to learn English language. This research is a procedural one conducted on a sample of 24 students at grade 9 in the period of the first semester of the academic year 2019-2020.

\section{The Aim of the Study}

The aim of this research is to know the effect of using active strategies and different methods of reinforcement the students while studying English language to raise their motivation of Grade Nine students and to improve their performance in English subject.

\section{Significance of the Study}

English teachers may implement diversity of strategies to motivate and encourage their students and engage them in the process of learning English language. This study may provide the English teacher with some ideas and techniques that would help them to motivate their students for improving leaning.

\section{Research Questions}

I. Are the students academically good in English language?

II. Are the students motivated to learn English?

III. Are the enhancement methods utilized in class are effective to motivate the students? 
IV. Is there any relationship between the academic achievement (the academic performance) and students' motivation?

\section{Hypotheses}

I. The students are academically good at English language.

II. The students are motivated to learn the English language.

III. The enhancement methods utilized in class are effective to motivate the students for more achievements.

IV. There is a relationship between the academic achievement (the academic performance) and students' motivation.

\section{Literature Review}

The previous related literature and research about the problem of non-motivation for learning English language is presented in the following section.

\subsection{Essential Concepts}

The are some essential concepts related to this study which should be well-defined such as:

A. Motivation: is (the force that drives an individual to perform a behavior in order to satisfy the need) and represents the goal or (the desire or goal that the individual seeks to achieve and is the emitter that works to reduce the motivation) [3].

\section{B. Intrinsic Motivation vs. Extrinsic Motivation}

There are many definitions of intrinsic and extrinsic motivation for learning languages. The distinction between these two concepts is well-known in psychological motivational theory. As we concern with second language learning (SLL), the definitions that is presented by Heider [4] (is adopted in this study. He defines intrinsic motivation as "actions or outcomes which can be perceived as personally caused or as a result of impersonal causes". So, it is self-motivation in which a student moves to act for the fun or 
challenge entailed rather than because of external prods, pressures, or rewards. Therefore, it results in high-quality learning and creativity. Whereas, extrinsic motivation, refers to "doing something because it leads to a separable outcome" [4]. In other words, extrinsic motivation refers to doing an activity simply for the satisfaction of the activity itself, rather than its instrumental significance. Hence, it is mainly associated with low student interest, persistence, and engagement.

C. Motivation for learning: It is the group of feelings that motivates the learner to engage in learning activities which lead to achieving the intended goals. It is also an essential necessity for learning to happen. It must be noted here that without it active learning does not happen. However, there are multiple sources of motivation for learning, including:

i. External sources such as the teacher, school administration, parents, or even peers. The learner may accept to learn in pursuit of "seeking to satisfy the teacher and gain his/her admiration or satisfaction" for his/her parents and obtain financial or moral encouragement from them.

ii. Internal sources are the learner himself/herself, where s/he offers to learn, driven by an "internal desire to satisfy himself /herself and seek to feel the pleasure of learning and gain knowledge."[6].

D. Low motivation to learn, is the behavior in which students demonstrate their feeling of boredom, withdrawal, inadequacy, excitement, and lack of participation in class and school activities. Manifestations of this problem and the symptoms that appear on students through the observation and the questionnaire are:

- Distraction.

- Preoccupation with others' purposes.

- Preoccupation with disturbing others as it raises class problems.

- Forgetting the duties and neglecting to solve them. 
- Forget everything related to class learning from materials and requirements such as books, notebooks and pens.

- Low perseverance in continuing to do the duty or tasks entrusted to him.

- Neglecting to abide by the instructions and laws of the class and school.

- The frequent absence from school.

- Hatred of the school until s/he feels the inconvenience of the seat on which he sits and grumbles about the large number of school subjects and follows classes and exams.

- Late morning and school dropout.

- Failure and achievement delay as a result of not making the effort appropriately with their capabilities.

- Not paying much attention to the rewards that may be offered to them [7].

\subsection{Reasons of Low Motivation for Learning}

The reasons for the lack of motivation are many, but first, it must be emphasized that each academic stage has its own circumstances, and the motivation ratio differs from one stage to another and from student to another, as well as the reasons. Nevertheless, these reasons can be limited to the following factors: the student himself/herself, teacher, family, environment. However, this study concerns with the students and the main reasons that lead to low motivation including:

1. Lack of readiness to learn from two aspects: The first is natural, such as being at a younger age than his peers, and s/he does not have the necessary preparations for learning, or her/his growth is slow compared to her/his peers, as for the second, especially as the lack of concepts and pre- experiences which is necessary for the new learning.

2. The student's lack of interest in learning mainly in addition to the lack of clarity of his vision for her/his future, where the student does not realize the importance of continuing to learn, 
but only cares for the job which gives her/ him a salary that s/he will live on as quickly as possible.

3. The absence of mature living models for students to imitate [8].

\subsection{Students' Motivation and Satisfaction}

Raising up the level of student motivation is a primary goal mentioned in the national development strategy of the State of Qatar, and it remains a fundamental concern for parents of students and educators in the education system from kindergarten through grade 12 [9]. If the students are bored from their school, or they make a negligible effort, or they miss frequently, their education will be negatively affected by this. Thus, it is a fundamental part of the teacher's mandate to prepare intrinsic motivations ideas and activities to stimulate her/his students for actively and successfully learning.

\section{Methodology}

This section discusses the method/s that is implemented in this study, including collecting data, the questionnaire, exams conducted on the target students, data analysis, discussing the findings, presenting the results and proposing suggestions and recommendations. However, in order to analyze the data accurately, both qualitative and quantitative approaches are used.

\subsection{The Subjects}

The subjects that are exposed for this study are 24 students at grade 9 in Fatima Al-Zahra'a Preparatory School for Girls/ in Qatar, in the first semester of the academic year 2019-2020. The subjects' age is between 15 and 16 years old. They are all females.

\subsection{Preparation Details}

The questionnaire, which is created for the purpose of this research, is utilized to collect data. It consists of 8 questions (see appendix 1). On the other hand, the target students have undergone two exams to 
approve the effectiveness of the motivation strategies used throughout the first semester to motivate and encourage students for more learning achievement.

\subsection{Procedures and Techniques}

To examine the effectiveness of motivation strategies conducted on the target sample, the researcher has followed different techniques to motivate her students and assist them to feel delighted while learning English language during the lesson. As a result, the teacher has conducted active learning strategies including games, technology tools as well as using different kinds of stimulation rewards to the distinguished students who participate actively in during the lesson [10].

However, this study, will focus on the extrinsic ways of motivation rather than intrinsic ones. Therefore, the teacher has motivated her students verbally, using expressions like (excellent, keep up, fantastic etc.) and nonverbally. As for non-verbally, the teacher has implemented two types of stimulation:

A. Individual Competitions; is performed during the lesson in which the teacher holds a competition among the students and rewards the distinguished ones ( the students who answer first correctly and quickly, or who answer high critical thinking question) with a star to be stuck at the first page in the specific month of the $1^{\text {st }}$ semester (September or October, or, November) to get them used to the method of stimulation for the rest of the year. Then, those stars are calculated at the end of each month. The highest number of stars that the student has got will, thus, be rewarded for either a free time or free homework or full mark in participation evaluation section. For example, in October, Sara has participated many times throughout the lessons, and she got the highest number of stars in the class. As a result, Sara will be rewarded to choose one of the above-mentioned rewards.

B. Groups Competitions: is performed throughout the lesson in which the teacher holds a competition among the groups, (mainly 5 groups ) rewards the distinguished ones according the following criteria : 
1. time limit

2. discipline

3. the accuracy of the work

4. cooperation between the team members

\subsubsection{Lesson Stages}

The lessons which are followed in this study includes different related intervals to accomplish the designed objectives as.

1. The starter of the lesson.

2. Raising previous experiences.

3. Motivating students.

4. Opening student learning centers.

5. The contents of the lesson.

The teacher was very careful about the contents of the lesson which mainly involve the following:

A. Writing the title of the lesson on the board.

B. Explaining the importance of the present lesson to engage the students in the activities of the lesson.

C. Writing the objectives of the lesson on the board and discuss them with the students in a very simple way.

D. Writing the key words on the board and keep them tile the end of the lesson.

E. Using different active learning strategies to stimulate the learners' previous experiences and relate them to the new experiences (the role of the teacher).

F. The starter (warm up) of the lesson should be attractive such as a hook question or a story or video or a problem or a picture ...etc. Accordingly, the more creative starter of the students the 
more motivated students will be to learn, which leads to achieving the objectives of the lesson. Therefore, the teacher should plan very well for the starter in particular, and for the next steps of the lesson in general.

\subsubsection{The Teaching Stages/ Presenting the Lesson}

It is important to train students to be self-learners that students apply the active learning and its strategies which develop all the learners' skills to accomplish the lesson's objectives.

To engage the students in the process of learning, during this, the teacher diversifies the activities that will be presented to them. For each objective, there must be three types activities consider the patterns of learners- (auditory - visual - kinesthetic). Moreover, the teacher provides help for self-learning student, and be a facilitator and mentor interfere with the right time for anyone needs help, provides feedback motivation and performance enhancement the students.

\subsubsection{The Objectives Stage}

The obvious question that imposes itself in this respect is "How to achieve the objectives actively where the student works more than the teacher? At this stage, the role of the teacher is essential and involves the following steps:

1- setting the objectives.

2- providing worksheets.

3- determining the time of each activity.

4- implementing diversity of activities.

5- choosing an appropriate teaching strategy.

On the other hand, the student should participate maximum $70 \%$ of the lesson's activities and leave $30 \%$ for the teacher to present the lesson, explain the difficult points to the class and to give feedback for the 
students during the lesson. In reading lesson for instance, the lesson passes through different stages. The first stage in which the teacher gives the text to students and then ask them to skim the extract to find the main idea. Then, analysis stage in which they read the text to analyze it into its structure by answering some comprehensive questions (why, who, where, when, what...etc.) which includes some critical thinking questions. Part of the students' duty is to search for new vocabulary and write down questions they do not know. Then, they discuss the difficult questions. During the lesson, the students may describe pictures, watch videos and take notes and, so on. Thus, by time, they gain the language skills (speaking, reading, listening and writing).

Synthesis is the third stage: at which the students express their understanding throughout filling in the graphic organizer or tables or maps of concepts or cause and effect, and others and here it investigates the last element in the card which is the practice of higher thinking skills (analysis and synthesis).

The sources of knowledge that can be provided to students are cards about the lesson - dictionary of languages - internet sites - the teacher's brochure - textbooks - the teacher (as director and facilitator) and sometimes, expert parents as experts and supporters.

To sum up , the role of the learners is to read - write - meditate - listen -self-learn - analyze the textsearch for sources of knowledge available to them by the teacher - use and apply the required teaching strategy- to fill in the graphic organizer [11].

Through all the above is in the teaching stage, the goals are achieved, and the learners obtain:

- Intellectually engaging in reading and analysis, and sensory in drawing and training, emotionally, and cooperating with each other between them and interact in the lesson

- acquire new information and knowledge. 
- have research skills, communicate, ability to ask questions - extract information - summarize and analyze. Synthesize and others.

- linking what they have learned with the reality of life, so what learners gain from knowledge and skills must be linked to their lives.

\subsubsection{The Assessment Stage}

It is an important stage in which the teacher measures the achievement of the planned objectives. There are three main ways for the evaluation:

1. Pre- evaluation which should be carried out before the lesson of the learning schedule.

2. Constructive evaluation which should be during the lesson.

3. Post- evaluation which should be at end of the lesson. For example, learning table in the box, or a question such as "What did you learn?" Or pamphlets summarizing what they have understood in the lesson.

However, the teacher can use any other evaluation strategy to assess the students' deep understanding of the lesson's material.

In this case, the teacher plays crucial role to diagnose the problem, follow active strategies to solve the problem and finally assess the efficiency of these strategies.

\section{Data Analysis and Discussion}

The data of this study is collected from two sources. The first, is a questionnaire designed to show the problem of students' low motivation for learning English in the Preparatory Schools in Qatar and the Fatima Al-Zahraa Prep. is only a sample. The second source is the scores that the students got in English subject in the Mid and Final Exams of the 1st Semester 2019. Two procedures are followed to analyze the data quantitively and qualitatively as shown in sections (8.1 and 8.2) below. 


\subsection{The Analysis of the Questionnaire}

A questionnaire is mainly designed in both English and Arabic for the purpose of this study and the data is collected and analyzed. It consists of eight questions and is distributed to 50 students selected randomly from grade 9 in Fatima Al-Zahra'a Preparatory School for Girls as shown in figures 1- 9. All the questions are consented to improve the students' motivation and readiness to study English language.

The Figures below show the percentage of the students' responses to the eight questions which considered to prove two essential problems ; the first is that students have weak academic foundation in English language accumulated from the previous grades and the second is that the students are not motivated to study English for different reasons.

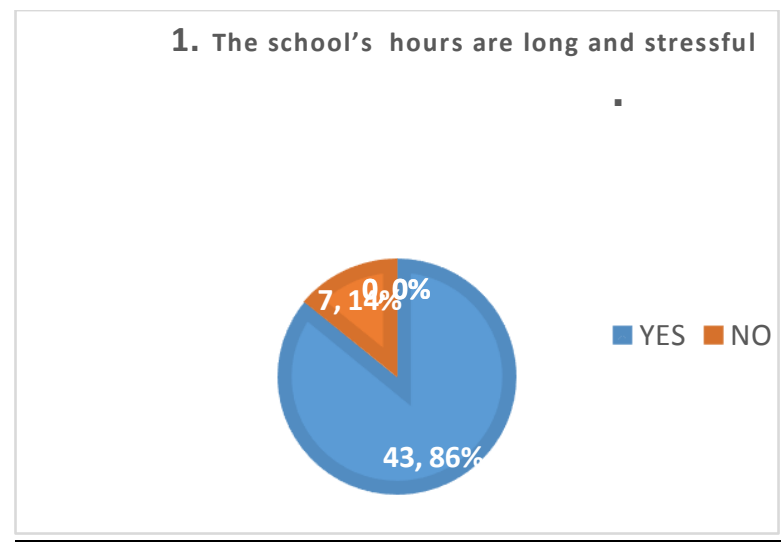

Figure (1): Percentage of question (1)

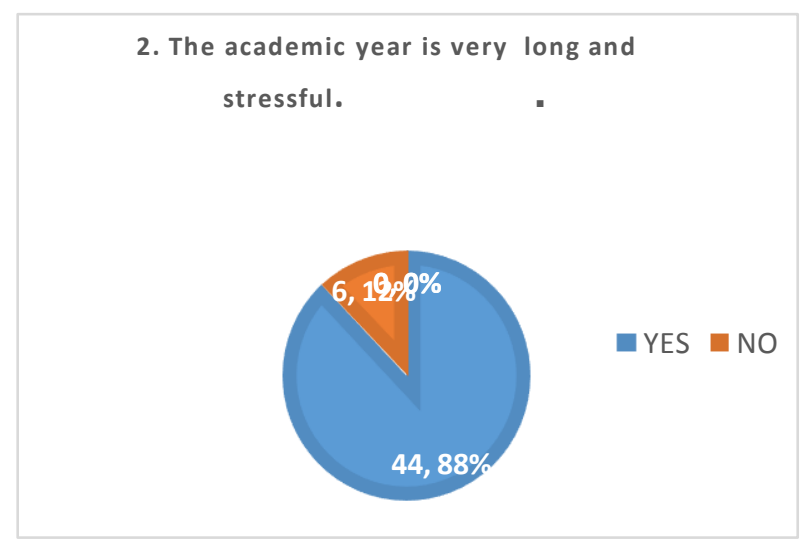

Figure (2): percentage of question (2) 
3. My foundation is weak at

English language .

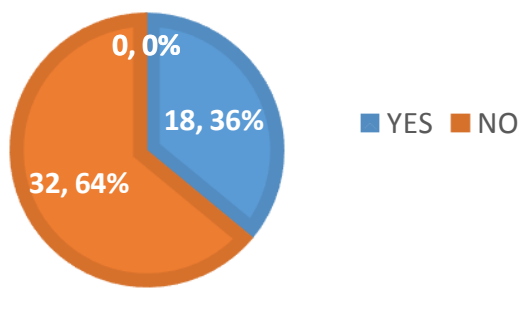

Figure (3): Percentage of question (3)

5. I feel bored during the English lesson.

\section{$0,0 \%$}

$28,56 \%{ }^{22,44 \%} \quad-$ YES $=$ NO

Figure (5): Percentage of question (5)

7. I receive appropriate motivation when I participate in the class.

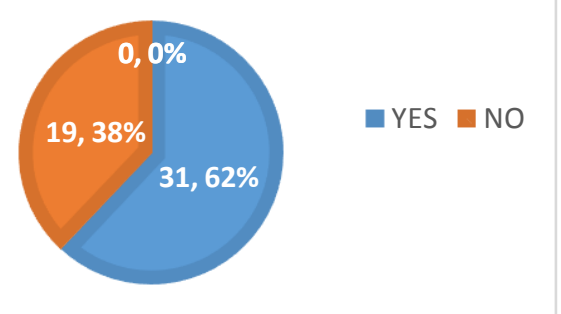

Figure (7): Percentage for question (7)
4. Weekly the English teacher assigns me a lot of homework and I feel bored.

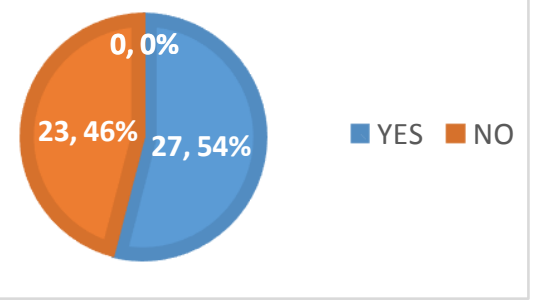

Figure (4): Percentage of question (4)

6. I am satisfied with my reinforcement style of the teacher while taking English lesson.

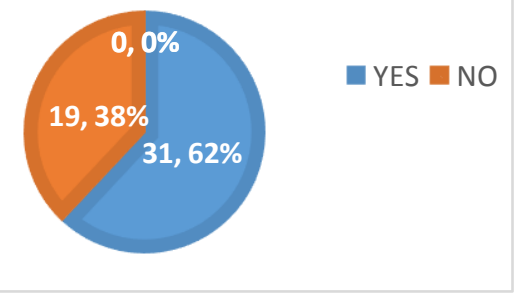

Figure (6): Percentage of question (6)

8. The teacher uses teaching methods and techniques that grab my attention to the lesson.

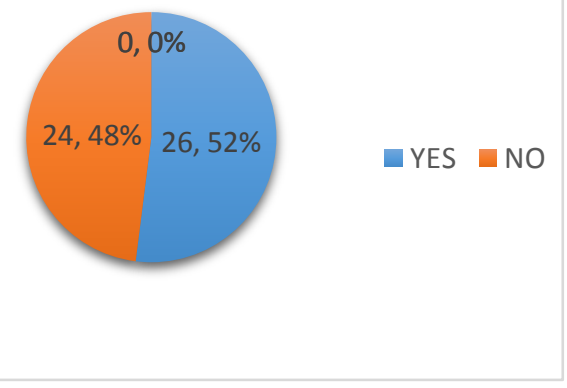

Figure (8): Percentage for question (8) 


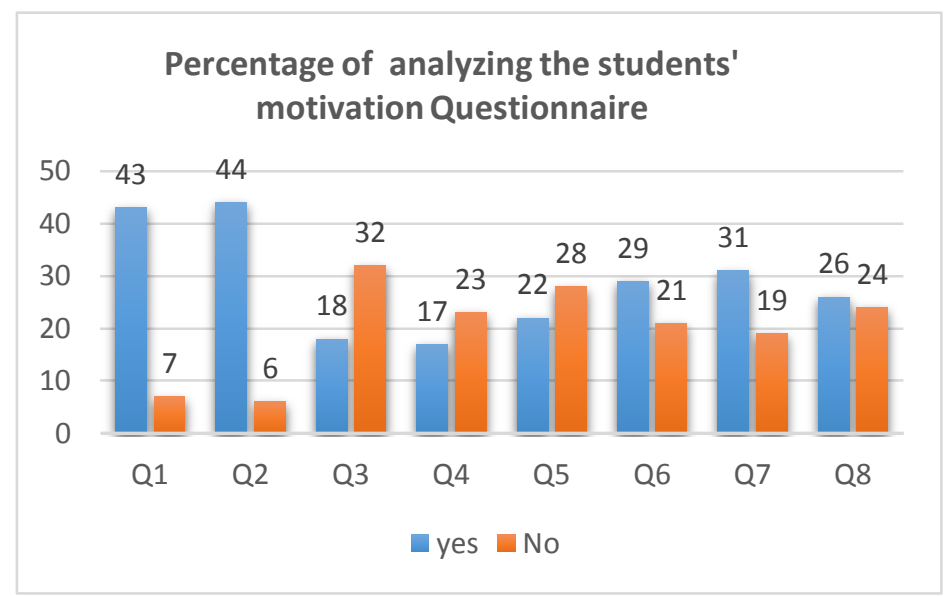

Figure (9): Percentage of the student answers for all the questions

In the light of the above findings, it is obvious that the students have suffered from the long academic learning day and that makes students feel bored and unwilling to study (figures 1,2). This is supported by Al-Mansouri, [11] who pointed out that all scientific studies have proven that the students do not comprehend any information after one o'clock p.m. Moreover, he confirmed, implicitly, the necessity to reduce the study time in the school and follow the Gulf academic systems such as that followed by Kuwait referring that those systems are strong and are among the highest in the ranking of the strength and quality of educational curricula. In this respect, some Qatari specialists in the Ministry of Education and Higher Education have agreed that reducing working hours for teacher as well as students and meeting their families at the lunch table daily and early is insufficiency contributed to increasing family stability which resulted into greater productivity. Al-Nuaimi added that productivity is not related to long working hours, as productive people can give better productivity with fewer hours [13].

Al-Bayeh ( 2018) [12] emphasized that a fundamental reason for students' failure in the English language subject is to use traditional teaching methods, as well as a lack of motivation among students.

Regarding question 3 (figure 3) the percentage shows that most of the students have accumulated weaknesses in English subject. In this respect, Al-Sulaiti (2018) [14] , the educational expert in Qatar, attributed the reason for the high failure rate in the subject of the English language in high school 
students to the presence of a cumulative weakness in the subject of the English language and this weakness moves with them to the next class which constitutes a difficulty in dealing with it in the advanced stages. Therefore, this constitutes a difficulty in dealing with it in the advanced stages by traditional methods, thus the student moves to the preparatory stage and then to the secondary stage with a major shift in the quantity and quality of the books and the prescribed materials. Thus, it is evident that the students have a cumulative academic weakness from the previous stages. Consequently, the first hypothesis has been set aside.

The students' responds to question 4 show that most of the students feel board because they have got a lot of homework during the week (figure 4) above. There is a great benefit to homework and that it is important to student success. Some studies have shown a relationship between test scores and homework. It also establishes the important skills as organization, time management and critical thinking. However, homework does not have to be an overload - it can be assigned using 10-minute homework because assigning and grading homework takes up valuable time and initiates stress. On the other hand, long homework does not leave time for family, friends, volunteering, sports, or hobbies. Some studies in the field of education have shown a relationship between test scores and homework [15].

Concerning question 5 , the ratio $56 \%$ of the students do not feel bored during English lesson whereas $44 \%$ do not. Accordingly, it can be seen from that the two ratios are very close (figure 5). While most of the students are satisfied with their reinforcement style of the teacher while taking English lesson and receive appropriate motivation when they participate in the class as shown in figures (6 \& 7). Accordingly, the second hypothesis is refuted.

The method of teaching is very important to grab the students' attention to the lesson, but most successful results depend on many factors: the teacher, the topic of the lesson, the available materials 
...etc. however, the students' responses indicate that almost the same percentage ( figure 8). Figure 9 summarizes the percentages of the student's answers for all the questions.

\section{2 The Analysis of Mid and Final Exams of the 1st Semester 2019}

The procedures mentioned in section (7) have been applied on the students in two exams during three academic months. It is worth mentioning that these exams are officially approved by the Ministry of Education and Higher Education. The first, is taken in the mid of the first semester, after two months of the study and the second, is at the End of the First Semester Exam.

The marks of the mid semester exam are out of $30 \%$ and figures $10 \& 11$ show the number of successful and failed students respectively in the Mid Semester Exam 2019. It is revealed that only eight students out of twenty-five have passed the exam whereas seventeen of them have been failed.

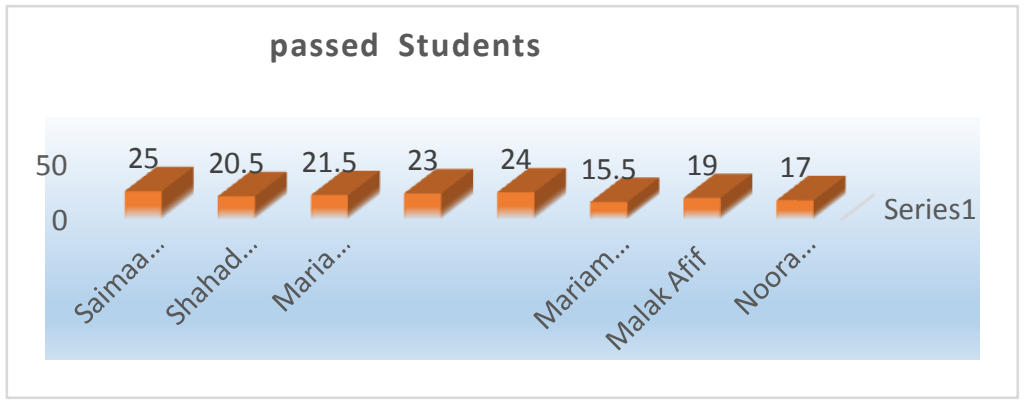

Figure (10): The Passed Students in the Mid Semester Exam 2019 out of $30 \%$.

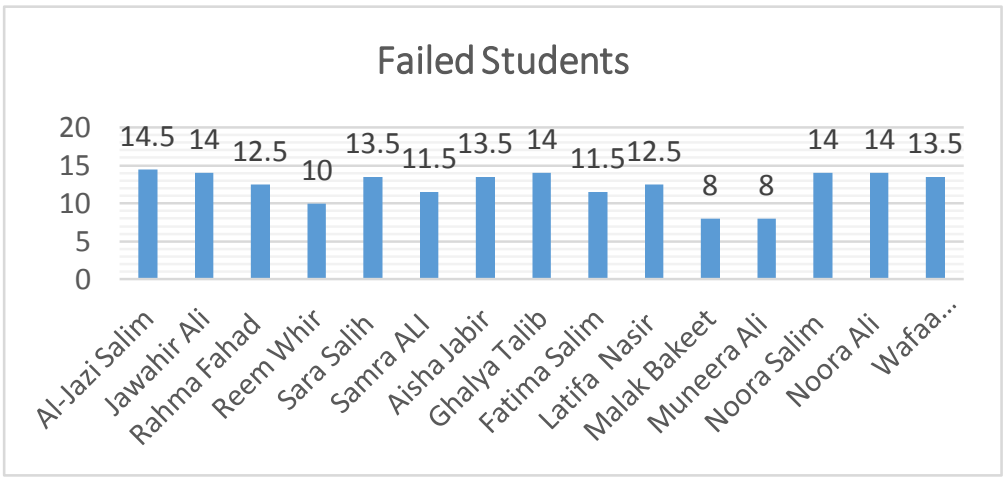

Figure (11): The Failed Students in the Mid Semester Exam 2019. 


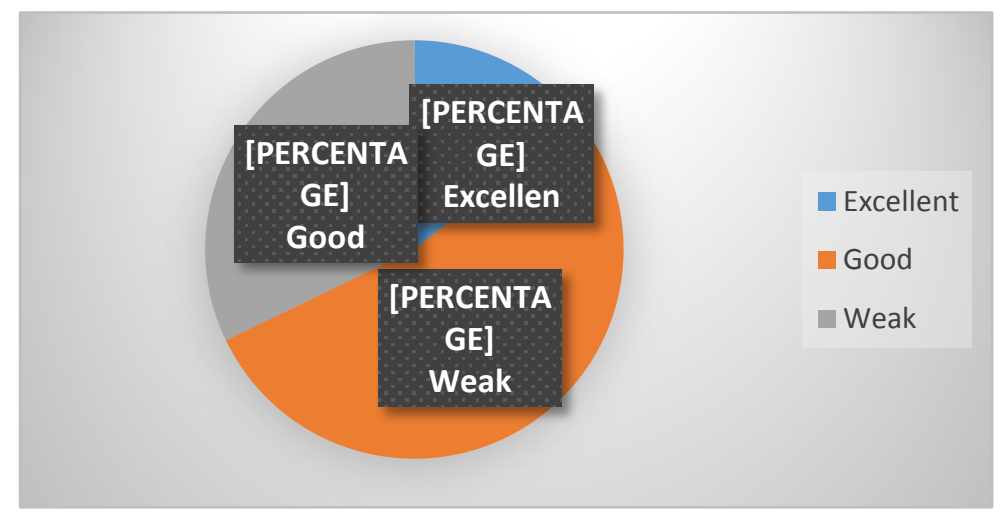

\section{Figure (12): The Percentage of Excellent, Good and Weak students in the Mid Semester Exam.}

The large number of students' failure and their low marks shown in figure 11 are due to the weak foundation of the students previously in English language, in general, and to the short period for the application of motivation strategies around 45 days. Figure 12 shows that $14 \%$ of the students has got Excellent rank and $32 \%$ of the students has got good rank whereas $54 \%$ of the students has got weak rank.

Hence, the results of this exam obviously show the weak standard of the student's English language, moreover the teacher's observation have shown a low motivation to learn English. Those remarks answer the first and the second questions in this study.

In contrast, the results of the students in the End Semester Exam are much better than the results of the students in Mid Semester Exam as shown in Figures 13-15. The marks of the end semester exam is out of $50 \%$ and figures 13 and 14 show the number of passed and failed students respectively in the End Semester Exam 2019. Figure 13 shows that twenty-one of the students have passed the exam whereas only two have failed (figure 14). It also shows not only that the number of passed students has doubled, but that their marks were also qualitatively distinctive. 


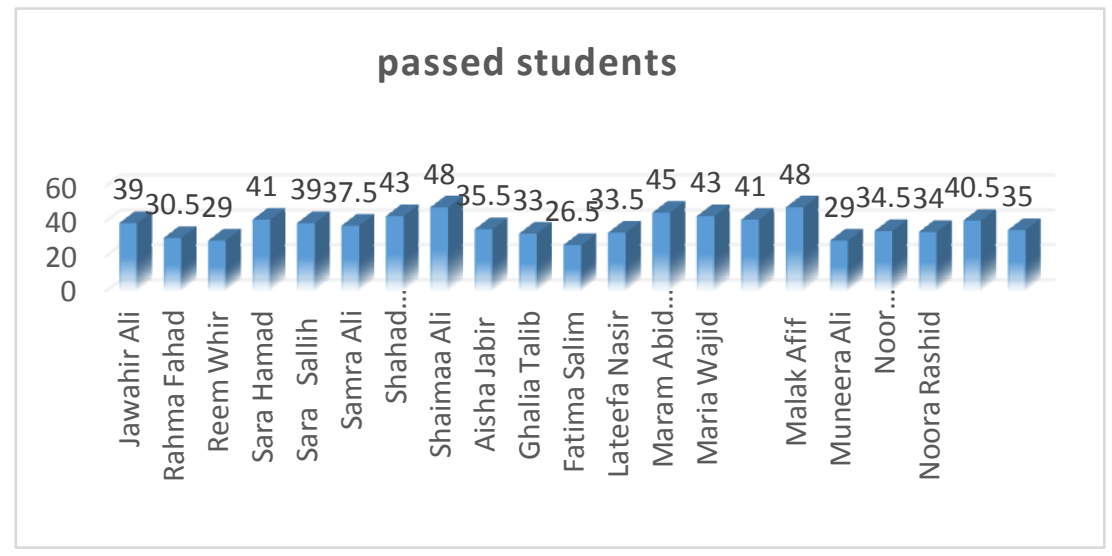

Figure (13): The number of the passed students at the End Semester Exam 2019 out of 50\%.

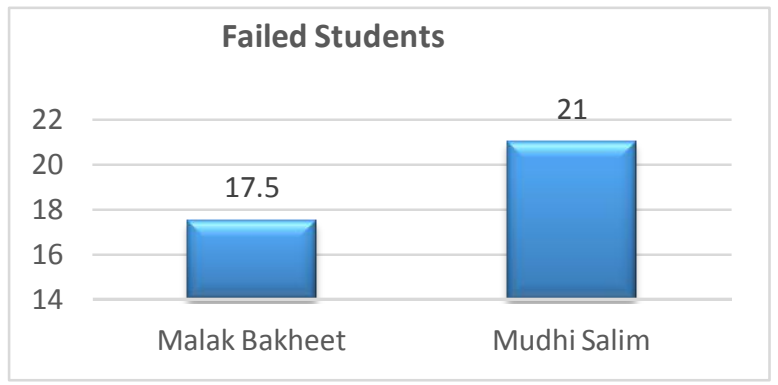

Figure (14): The number of the failed students in the End Semester Exam 2019.

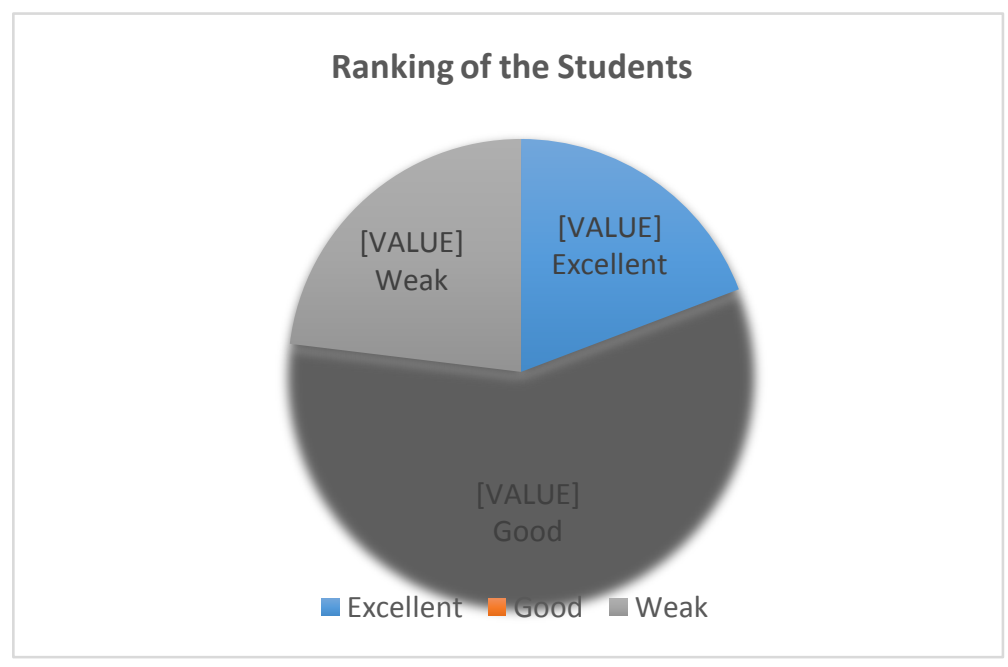

Figure (15): The Percentage of Excellent, Good and Weak students in the End Semester Exam 2019.

The ranks of the examined students is show in figure 15 and they are distributed as $19 \%$ of them has got Excellent rank (above 45\%) and 58\% of the students has got the good rank (between 25\% -44\%) whereas $23 \%$ of the students has got weak rank (below 25\%). 
The impressive results of students in the end semester exam demonstrate the effectiveness of the strategies that implemented as they have enabled students in raising their motivation to learn English language throughout improving their marks and language performance despite the limited period. These strategies become part of the educational process and will have a positive impact on their language level in the next semesters. The results of this exam show apparently that the enhancement methods utilized in class are effective to motivate the students and there is consistent relationship between the academic achievement (the academic performance) and students' motivation. Hence, student's success answers questions three and four raised earlier.

\section{Conclusion and Recommendations}

This research has approved that using active motivation strategies raise and enhance the students' willingness to learn English. Those strategies have also encouraged the students to interact effectively, individually and in groups and inspired the student-centered learning. Moreover, such strategies provided a challenge, in which the students need their concentration to fulfil the tasks properly with the limit of time and this will strengthen their mental work. Nevertheless, not all students are motivated by the same values, needs or desires.

However, teachers may use / create other techniques and methods to improve their students' level of learning English language.

In the light of the results of this study, some tips are recommended and listed below to improve the students' motivation for better learning:

1. Creating the desire of knowledge among students may be achieved throughout the teachers, parents, society, and the media.

2. Activating the role of extra-curricular activities, trips, exhibitions, sports and the library. 
3. Granting the students degree of freedom that relieves them from the pressure they experienced throughout the long day of study.

4. Assisting the students in determining their future goals early, as this will be an incentive for them to learn, mainly played by the academic coordinator in the school.

5. Satisfying the students 'basic needs such as free time, praying, self-confidence, respect, encouragement, and other values.

6. Reducing the school hours to at least one hour per a day, to give the students a better chance to be at home earlier, take enough rest and be near to their families.

7. Teachers should avoid extremes when assigning homework, i.e., 10 minutes' time homework/ assignment is enough. 


\section{References:}

$$
\begin{aligned}
& \text { [1] [جيه السباعي ، دافعية الطلاب للتعليم تتراجع، جريدة الامار ات اليوم، } 28 \text { ديسمبر 2011، دبي. } \\
& \text { [2] صندح النعيمي ، الأخصائيون النفسيون يناقشون دافعية الطلاب للتعليم، جريدة الوطن 1مايو / أيار 2018م. }
\end{aligned}
$$

[ 3] Marriam -Webster Dictionary. https://www.howtopronounce.com/merriam-dictionary

[4] F. Heider, The psychology of interpersonal relations. New York: John Wiley (1958).

[5] M. Ryan Richard and L. Deci Edward, Intrinsic and Extrinsic Motivations: Classic Definitions and New Directions, Contemporary Educational Psychology, 25, doi:10.1006/ceps.1999.1020, available online at http://www.idealibrary.com.

[6] E.A. Patall, B.J. Sylvesterand and C.W. Han, The role of competence in the effects of choice on motivation. Journal of Experimental Social Psychology, 50(1)(2014)27-44. doi:10.1016/j. jesp.2013.09.002. p.113

[7] C. Howey Steven, "Factors in Student Motivation" ‘www.nacada.ksu.edu, Retrieved 25/6/2018.

$$
\text { [8) مروة حسين علي ، العو امل النفسية المؤثرة في الأداء الدراسي، ص دار أمجد للنشر والتوزيع، عمان/ الأردن ، الساعي ص }
$$

[9] معهد البحوث الاجتماعية والاقتصادية المسحيّة QES , " تقرير دافعية الطلاب و مشاركة أولياء الأمور "، التعليم في قطر، جامعة

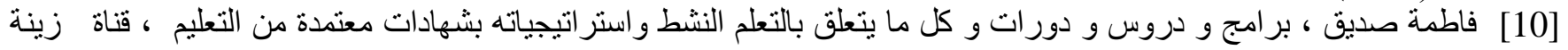

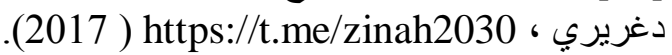

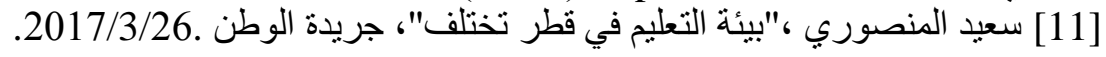
[12] هبة البيه ، 6 أسباب وراء ارتفاع نسب الرسوب في الإنجليزية، جريدة الراية القطرية ، 5 يوليو/ تموز 2018م. [13] فهد النعيمي ، هذا ما ينتجه تقليص ساعات العمل ، جريدة الثرق العدد 11525 ، 5 يناير 2020 ، قطر. [14] سلمان السليطي ، " 6 أسباب ور اء ارتفاع نسب الرسوب في الإنجليزية"، جريدة الراية القطرية ، 5 يوليو / تموز 2018م.

[15] D. L. Haury, "Why is Homework Important?", The ERIC Review,(1999).

[16] J. Reamen, Motivational Factors that Enhance Students Learning/Achievement, Journal of Teaching and Education, 04(02):323-332 (2015). Available at SSRN: https://ssrn.com/abstract=2714297 or http://dx.doi.org/10.2139/ssrn.2714297 